\title{
PENGARUH METODA KONSELING TEMAN SEBAYA TERHADAP PENGETAHUAN REMAJA TENTANG OBESITAS DI SEKOLAH MENENGAH KEJURUAN NEGERI I RANGKASBITUNG TAHUN 2016
}

\begin{abstract}
Ahmad, Kadar Kuswandi*
Abstrak

Obesitas adalah keadaan dimana terdapat penimbunan lemak di dalam tubuh yang berlebihan. Pada tahun 2013, di Indonesia prevalensi obesitas penduduk usia lebih dari 18 tahun mencapai $15,4 \%$.Tujuan penelitian ini adalah diketahuinya pengaruh metoda konseling teman sebaya terhadap pengetahuan remaja tentang obesitas di Sekolah Menengah Kejuruan I Rangkasbitung Tahun 2016.

Desain penelitian yang digunakan adalah Quasi ekperimen. Populasi dalam penelitian ini adalah siswa Sekolah Menengah Kejuruan I Rangkasbitung kelas XI. Sampel diambil dari kelas yang berbeda. Satu kelas diberikan promosi kesehatan dengan metoda ceramah yang dilakukan oleh peneliti (kelompok control) dan satu kelas lagi diberikan promosi kesehatan dengan metoda konseling teman sebaya yang dilakukan oleh siswa yang telah diberikan pelatihan tentang konseling teman sebaya mengenai obesitas (kelompok perlakuan). Pengumpulan data dilakukan dua kali yaitu sebelum diberikan promosi kesehatan dengan metoda ceramah dan setelah diberikan ceramah pada kelompok control serta sebelum dilakukan promosi kesehatan dengan metoda konseling teman sebaya dan setelah pemberian konseling sebaya pada kelompok perlakuan Analisis data menggunakan perangkat computer dengan uji $\mathrm{T}$ dependen pada masing-masing kelompok dan uji $\mathrm{T}$ independen pada kelompok kasus dan kelompok control.

Hasil penelitian menunjukkan bahwa rata - rata pengetahuan siswa tentang obesitas pada kelompok Kontrol untuk pengukuran pertama adalah 5,755 dengan standar deviasi 1,04, dan pengukuran kedua rata-rata pengetahuan 6.475 dengan standar deviasi 1.21. Hasil uji statistik ada perbedaan yang signifikan rata - rata pengetahuan siswa pada pengukuran pertama dan kedua Sementara itu, rata - rata pengetahuan siswa tentang obesitas pada kelompok perlakuan, pengukuran pertama adalah 5,500 dengan standar deviasi 0.88 . dan pengukuran kedua rata-rata pengetahuan 6.427 dengan standar deviasi 1.10. Hasil uji statistik menunjukan ada perbedaan yang signifikan rata -rata pengetahuan siswa pada pengukuran pertama dan kedua. Hasil analisis lebih lanjut,menunjukan rata - rata pengetahuan siswa tentang obesitas pada kelompok perlakuan adalah 5,500 dengan standar deviasi 0.88, dan pada kelompok kontrol rata-rata pengetahuan 5.755 dengan standar deviasi 1.04. Hasil uji stantistik menunjukkan tidak ada perbedaan yang signifikan rata - rata pengetahuan siswa pada kelompok perlakuanj / teman sebaya dengan kelompok kontrol.

Perlunya tenaga kesehatan atau pendidik mengembangkan konseling teman sebaya sebagai pilihan metoda dalam memberikan penyuluhan kesehatan
\end{abstract}

Daftar Pustaka ( 16 : 1998-2013)

*Dosen Jurusan Analis Kesehatan Poltekkes Kemenkes Banten 


\section{Latar Belakang}

Obesitas adalah keadaan dimana terdapat penimbunan lemak di dalam tubuh yang berlebihan.Umumnya obesitas ditentukan menggunakan Indeks Masa Tubuh (IMT) atau Body Mass Indeks (BMI) yaitu perbandingan berat badan (dalam kilogram) dengan kuadrat tinggi badan (dalam meter). Saat ini, obesitas merupakan permasalahan diberbagai negara di dunia.

Berdasarkan fakta di masyarakat, masih banyak pengetahuan dan pemhaman masyarakat termasuk remaja yang masih kurang tentang kesehatan, khususnya tentang obesitas, walaupun pemerintah telah banyak melakukan upaya promosi kesehatan dengan berbagai metode yang digunakan. Metode promosi kesehatan yang sering dilakukan petugas kesehatan adalah melalui ceramah langsung pada kelompok sasaran, atau pemasangan banner di tempat tertentu sementara metode lain seperti melakukan konseling sebaya masih kurang dilakukan para praktisi kesehatan. Sekolah Menengah Kejuruan (SMK) Negeri I Rangkasbitung merupakan salah satu sekolah kejuruan favorit di Kabupaten Lebak dengan jumlah siswa yang cukup banyak. Di sekolah ini telah ada program Pelayanan Kesehatan Peduli Remaja (PKPR) yang dibina oleh dinas kesehatan Kabupaten Lebak, namun program ini masih belum dapat berjalan dengan baik. Berdasakan hal yang telah penulis uraikan tersebut, penulisi tertarik untuk mengkaji lebih dalam tentang upaya promosi kesehatan dengan metode konseling sebaya di Sekolah Menengah Kejuruan Negeri I Rangkasbitung terhadap pengetahuan remaja tentang obesitas.

\section{Metode Penelitian}

Desain Penelitian ini adalah dengan menggunakan desain Eksperimen Semu (Quasi Eksperimental Research).

Sampel pada penelitian ini adalah seluruh Siswa kelas XI AP 1 SMK Negeri I Rangkasbitung berjumlah 43 orang sebagai kelompok kontrol dan kelas XI AP III berjumlah 42 orang sebagai kelompok control; sehingga total sampel sebanyak 85 orang. Pemilihan sampel dilakukan berdasarkan jumlah siswa dalam kelas dan rata - rata prestasi siswa di masing-masing kelas berdasarkan perolehan nilai rapot siswa. Rata - rata nilai raport siswa pada kelas XI AP 1 lebih tinggi dibanding siswa kelas XI AP III, oleh karenanya kelas XI AP III dipilih sebagai kelompok perlakuan.

Pengumpulan data penelitian ini dengan menggunakan pretest posttest desain-metode. 
Tabel 1

Distribusi karakteristik Responden kelompok Kontrol siswa kelas II AP 1

SMKN I Rangkasbitung tahun 2016

\begin{tabular}{|c|c|c|c|}
\hline Variabel & Kategori & Jumlah & $\%$ \\
\hline \multirow{3}{*}{ Jenis Kelamin } & Laki-laki & 3 & 7,5 \\
\hline & Perempuan & 37 & 92,5 \\
\hline & Jumlah & 40 & 100 \\
\hline \multirow{4}{*}{ Umur } & 15 Thn & 6 & 15 \\
\hline & 16 tahun & 28 & 70 \\
\hline & 17 tahun & 6 & 15 \\
\hline & Jumlah & 40 & 100 \\
\hline \multirow{5}{*}{$\begin{array}{c}\text { Pendidikan } \\
\text { Ibu }\end{array}$} & SD & 15 & 37.5 \\
\hline & SLTP & 13 & 32,5 \\
\hline & SLTA & 10 & 25 \\
\hline & PT & 2 & 5 \\
\hline & Jumlah & 40 & 100 \\
\hline \multirow{3}{*}{$\begin{array}{c}\text { Pekerjaan } \\
\text { Bapak }\end{array}$} & PNS & 3 & 7,5 \\
\hline & Non PNS & 37 & 92,5 \\
\hline & Jumlah & 40 & 100 \\
\hline \multirow{3}{*}{$\begin{array}{c}\text { Kebiasaan } \\
\text { Makan sayur }\end{array}$} & Kurang & 29 & 72,5 \\
\hline & Cukup & 11 & 27,5 \\
\hline & Jumlah & 40 & 100 \\
\hline \multirow{3}{*}{$\begin{array}{l}\text { Kebiasaan } \\
\text { Olahraga }\end{array}$} & Kurang & 22 & 55 \\
\hline & Cukup & 18 & 45 \\
\hline & Jumlah & 40 & 100 \\
\hline
\end{tabular}

Tabel 2

Distribusi karakteristik Responden kelompok perlakuan siswa kelas II AP SMKN I Rangkasbitung tahun 2016

\begin{tabular}{|c|c|c|c|}
\hline Variabel & Kategori & $\begin{array}{c}\text { Jum- } \\
\text { lah }\end{array}$ & $\%$ \\
\hline \multirow{3}{*}{ Jenis Kelamin } & Laki-laki & 2 & 5 \\
\hline & Perempuan & 39 & 95 \\
\hline & Jumlah & 41 & 100 \\
\hline \multirow{4}{*}{ Umur } & 15 Thn & 8 & 19,5 \\
\hline & 16 tahun & 29 & 70,7 \\
\hline & 17 tahun & 4 & 9,8 \\
\hline & Jumlah & 41 & 100 \\
\hline \multirow{5}{*}{ Pendidikan Ibu } & SD & 14 & 34.1 \\
\hline & SLTP & 12 & 29,3 \\
\hline & SLTA & 13 & 31,7 \\
\hline & PT & 2 & 4,9 \\
\hline & Jumlah & 41 & 100 \\
\hline \multirow{3}{*}{$\begin{array}{c}\text { Pekerjaan } \\
\text { Bapak }\end{array}$} & PNS & 2 & 4,9 \\
\hline & Non PNS & 39 & 95.1 \\
\hline & Jumlah & 41 & 100 \\
\hline \multirow{3}{*}{$\begin{array}{c}\text { Kebiasaan } \\
\text { Makan sayur }\end{array}$} & Kurang & 38 & 92,7 \\
\hline & Cukup & 3 & 7,3 \\
\hline & Jumlah & 41 & 100 \\
\hline \multirow{3}{*}{$\begin{array}{l}\text { Kebiasaan } \\
\text { Olahraga }\end{array}$} & Kurang & 35 & 85,4 \\
\hline & Cukup & 6 & 14,6 \\
\hline & Jumlah & 41 & 100 \\
\hline
\end{tabular}

Tabel 3

Distribusi Pengetahuan Siswa tentang obesitas pada kelompok perlakuan Dan kelompok Kontrol di SMKN I Rangkasbitung Tahun 2016

\begin{tabular}{|c|c|c|c|c|c|}
\hline kelompok & Variabel & Mean & Skewness & SE & Skewness/SE \\
\hline perlakuan & pengetahuan & 5,500 & 0,423 & 0,369 & 1.146 \\
\hline Control & Pengetahuan & 5,755 & 0,326 & 0,374 & 0,871 \\
\hline
\end{tabular}

Tingkat Pengetahuan Siswa tentang Obesitas pada Kelompok perlakuan dan kelompok kontrol 
Tabel 4

Distribusi rata - rata pengetahuan siswa tentang obesitas menurut pengukuran pertama dan kedua pada Kelompok Perlakuan dan kelompok Kontrol di SMKN I Rangkasbitung tahun 2016

\begin{tabular}{|c|c|c|c|c|c|}
\hline Variabel & Mean & SD & SE & P Value & $\mathrm{N}$ \\
\hline \multicolumn{6}{|c|}{ Pengetahuan Kelompok Perlakuan } \\
\hline Pengukuran I & 5,500 & 0.88 & 0.14 & \multirow[b]{2}{*}{0,000} & \multirow[b]{2}{*}{41} \\
\hline Pengukuran II & 6.427 & 1.10 & 0.17 & & \\
\hline \multicolumn{6}{|c|}{ Pengetahuan Kelompok Kontrol } \\
\hline Pengukuran I & 5.755 & 1.04 & 0.16 & \multirow[b]{2}{*}{0.003} & \multirow[b]{2}{*}{40} \\
\hline Pengukuran II & 6.475 & 1.21 & 0.19 & & \\
\hline
\end{tabular}

Rata - rata pengetahuan siswa tentang obesitas pada kelompok Perlakuan untuk pengukuran pertama adalah 5,500 dengan standar deviasi 0.88. Pada pengukuran kedua didapat rata-rata pengetahuan 6.427 dengan standar deviasi 1.10. Terlihat nilai mean perbedaan antara pengukuran pertama dan kedua adalah 0,927 dengan standar deviasi 0.22. Hasil uji stantistik didapatkan nilai $\mathrm{p}=0.000$, maka dapat disimpulkan ada perbedaan yang signifikan antara rata -rata pengetahuan siswa pada pengukuran pertama dan kedua.
Sementara itu, rata - rata pengetahuan siswa tentang obesitas pada kelompok Kontrol untuk pengukuran pertama adalah 5,755 dengan standar deviasi 1,04. Pada pengukuran kedua didapat rata-rata pengetahuan 6.475 dengan standar deviasi 1.21. Terlihat nilai mean perbedaan antara pengukuran pertama dan kedua adalah 0,72 dengan standar deviasi 0.17. Hasil uji stantistik didapatkan nilai $\mathrm{p}=0.003$, maka

dapat disimpulkan ada Perbedaan Pengetahuan siswa tentang obesitas pada Kelompok Kontrol dan kelompok Perlakuan / teman Sebaya

Tabel 5.

Distribusi rata - rata pengetahuan siswa tentang obesitas menurut Metode konseling di SMKN I Rangkasbitung tahun 2016

\begin{tabular}{|c|c|c|c|c|c|}
\hline Pengetahuan & Mean & SD & SE & P Value & N \\
\hline Perlakuan & 5.500 & 0.88 & 0.13 & & 41 \\
\hline Kontrol & 5.755 & 1.04 & 0.16 & 0.239 & 40 \\
\hline
\end{tabular}


Rata - rata pengetahuan siswa tentang obesitas pada kelompok Perlakuan adalah 5,500 dengan standar deviasi 0.88. Sedangkan untuk kelompok kontrol rata-rata pengetahuan 5.755 dengan standar deviasi 1.04. Hasil uji stantistik didapatkan nilai $\mathrm{p}=0.239$, berarti bahwa pada alpha $5 \%$ terlihat tidak ada perbedaan yang signifikan rata-rata antara pengetahuan siswa pada kelompok perlakuan / teman sebaya dengan kelompok kontrol.

\section{Pembahasan}

1. Pengetahuan Siswa Tentang Obesitas pada Kelompok Perlakuan

Berhasil tidaknya peningkatan pengetahuan siswa, banyak bergantung kepada bagaimana proses belajar yang dialami siswa sebagai anak didik, karena dalam keseluruhan proses pendidikan di sekolah kegiatan belajar merupakan kegiatan yang paling pokok. Hasil penelitian menunjukkan bahwa rata - rata pengetahuan siswa tentang obesitas pada kelompok Perlakuan (metode teman sebaya) untuk pengukuran pertama 5,500 dengan standar deviasi 0.88 , dan pengukuran kedua 6.427 dengan standar deviasi 1.10, dengan nilai $\mathrm{p}=0.000$, maka dapat disimpulkan bahwa sacara statistic ada perbedaan yang signifikan antara rata -rata pengetahuan siswa pada pengukuran pertama dan kedua.

Perbedaan rata - rata pengetahuan siswa pada kelompok perlakuan pada pengukuran pertama dan kedua menunjukkan bahwa pemberian informasi tentang obesitas dengan metode konseling sebaya dapat meningkatkan pengetahuan siswa tentang obesitas. Perbedaan rata - rata pengetahuan siswa tentang obesitas tersebut dapat dipahami, karena dengan diberikannya informasi, siswa memperoleh tambahan pengetahuan baru tentang obesitas dibanding pengetahuan yang sudah dipahami sebelumnya. Selain metode saat memberikan informasi tentang obesitas, orang yang memberikan informasi juga dapat mempengaruhi terhadap pemahaman siswa mengenai obesitas. Penyuluh yang memberikan informasi obesitas pada kelompok siswa ini adalah para siswa yang terpilih sebagai kelompok teman sebaya yang telah mengikuti pelatihan tentang konseling teman sebaya tentang obesitas yang dilakukan oleh tim peneliti.

Kelompok ini selanjutnya berperan sebagai konselor teman sebaya dikelasnya bagi masing - masing kelompoknya. Melalui proses kelompok ini, terlihat ada perubahan rata - rata pengetahuan pada pengukuran kedua, yang menunjukkan adanya peningkatan. Hal ini berarti bahwa konseling teman sebaya dapat meningkatkan pengetahuan siswa tentang obesitas. Penelitian yang dilakukan Buhrmester, menunjukkan bahwa, pada masa remaja kedekatan hubungan dengan teman sebaya meningkat secara drastic, pada saat bersamaan kedekatan hubungan remaja dengan orang tua menurun secara drastis. Penelitian Buhrmester dikuatkan oleh temuan Nickerson \& Nagle bahwa pada masa remaja komunikasi dan kepercayaan terhadap orang tua berkurang dan beralih kepada teman sebaya. Hubungan yang baik diantara teman sebaya akan sangat membantu perkembangan social anak secara 
normal. Gladding mengungkapkan bahwa dalam interaksi teman sebaya memungkinkan terjadinya proses identifikasi, kerjasama dan proses kolaborasi. Proses - proses tersebut akan mewarnai proses pembentukan tingkah laku maupun peningkatan pemahaman dan pengetahuan remaja, oleh karena itu jelas dapat kita pahami metode konseling teman sebaya dapat meningkatkan pengetahuan remaja tentang obesitas.

Hasil penelitian ini sejalan dengan hasil penelitian Irianti tentang pengaruh pendidikan kesehatan reproduksi melalui metode pendidikan teman sebaya terhadap pengetahuan dan sikap remaja dalam pencegahan kehamilan tak diinginkan pada siswa di SMUN I Bandung yang menunjukan bahwa pendidikan kesehatan reproduksi melalui pendidikan teman sebaya dapat meningkatkan pengetahuan remaja tentang pencegahan kehamilan tidak diinginkan.

2. Pengetahuan Siswa Tentang Obesitas pada Kelompok Kontrol

Hasil penelitian didapatkan rata-rata nilai pengetahuan siswa kelompok kontrol pada pengukuran pertama 5,755 dan pada pengukuran ke dua 6,475 dengan nilai $\mathrm{p}=$ 0,003 . Hasil ini menunjukkan bahwa secara statistic ada perbedaan yang signifikan antara rata - rata pengetahuan siswa pada pengukuran pertama dan kedua.

Perbedaan rata - rata pengetahuan siswa pada kelompok kontrol pada pengukuran pertama dan kedua menunjukan bahwa pemberian informasi tentang obesitas dengan metode ceramah dapat meningkatkan pengetahuan siswa tentang obesitas. Perbedaan rata - rata pengetahuan siswa tentang obesitas tersebut dapat dipahami, karena dengan diberikannya informasi, siswa memperoleh tambahan pengetahuan baru tentang obesitas dibanding pengetahuan yang sudah dipahami sebelumnya.

Berdasarkan berbagai teori yang ada, menjelaskan bahwa banyak factor yang mempengaruhi pengetahuan seseorang, dan pemberian informasi jelas akan manambah pengetahuan seseorang, sebagaimana siklus terbangunnya kecerdasan seseorang yang dihimpun dari kumpulan informasi yang diperolehnya, lalu membentuk pengetahuan pengetahuan baru bagi seseorang. Selanjutnya pengetahuan - pengetahuan baru tersebut dihimpun, diproses dan dianalisis hingga akhirnya membentuk kecerdasan seseorang. Oleh karenanya sangat kita pahami adanya peningkatan rata - rata pengetahuan siswa tentang obesitas sebelum diberikan penyuluhan dengan setelah diberikan penyuluhan. Peningkatan rata - rata pengetahuan pada kelompok siswa ini, memang tidak terlampau tinggi, namun bila dicermati dari perolehan nilai masing-masing siswa, terlihat beberapa nilai siswa mengalami peningkatan yang cukup tinggi.

1. Perbedaan Pengetahuan siswa tentang obesitas pada Kelompok Kontrol dan kelompok Perlakuan / teman Sebaya

Hasil analisis dalam penelitian ini menunjukkan bahwa rata-rata nilai pengetahuan siswa tentang obesitas pada 
kelompok perlakuan (konseling teman sebaya) adalah 5.500 sementara pada kelompok control sebesar 5,755, dengan nilai $\mathrm{p}=0,239$. Hasil ini menunjukkan bahwa secara statistic pada alpha $5 \%$, tidak ada perbedaan yang signifikan antara rata - rata pengetahuan siswa tentang obesitas pada kelompok perlakuan dan kelompok kontrol.

Hasil ini menggambarkan bahwa intervensi penyuluhan dengan metode ceramah maupun melalui metode konseling tidak memberikan perbedaan yang bermakna terhadap rata - rata pengetahuan siswa tentang obesitas. Walaupun hasil penelitian ini tidak memberikan pebedaan yang bermakna, namun dapat kita cermati bahwa rata - rata pengetahuan siswa tentang obesitas pada kelompok perlakuan peningkatannya sedikit lebih tinggi dibandingkan dengan kelompok control pada pengukuran pertama dan kedua, oleh karenanya metode konseling teman sebaya dalam memberikan penyuluhan kesehatan bagi kelompok remaja tetap menjadi pilihan, mengingat karakteristik remaja memiliki kecenderungan yang kuat terhadap pengaruh kelompoknya dibanding kelompok lainnya.

Hasil penelitian ini berbeda dengan hasil penelitian yang dilakukan Hermanus W, dkk yang menjelaskan bahwa pengetahuan seksualitas siswa pada kelompok yang diberikan konseling teman sebaya (perlakuan) lebih tinggi dibandingkan kelompok control..

Hasil penelitian ini sejalan dengan hasil penelitiannya Martalena, dkk tentang hubungan kelompok teman sebaya dengan prestasi belajar siswa kelas XII di SMAN Padang Ganting, yang menjelaskan bahwa teman sebaya di SMA ini tidak terlalu berpengaruh dalam meningkatkan prestasi belajar siswa.

\section{Kesimpulan}

Berdasarkan hasil penelitian yang telah penulis uraikan pada bagian terdahulu, dapat penulis simpulkan sebagai berikut :

1. Rata - rata pengetahuan siswa tentang obesitas pada kelompok Perlakuan untuk pengukuran pertama adalah 5,500 dengan standar deviasi 0.88. Pada pengukuran kedua didapat rata-rata pengetahuan 6.427 dengan standar deviasi 1.10. Terlihat nilai mean perbedaan antara pengukuran pertama dan kedua adalah 0,927 dengan standar deviasi 0.22. Hasil uji statistik didapatkan nilai $\mathrm{p}=0.000$, maka dapat disimpulkan ada perbedaan yang signifikan antara rata -rata pengetahuan siswa pada pengukuran pertama dan kedua.

2. Rata - rata pengetahuan siswa tentang obesitas pada kelompok Kontrol untuk pengukuran pertama adalah 5,755 dengan standar deviasi 1,04. Pada pengukuran kedua didapat rata-rata pengetahuan 6.475 dengan standar deviasi 1.21. Terlihat nilai mean perbedaan antara pengukuran pertama dan kedua adalah 0,72 dengan standar deviasi 0.17. Hasil uji statistik didapatkan nilai $\mathrm{p}=0.003$, maka dapat disimpulkan ada perbedaan yang signifikan antara rata - rata pengetahuan siswa pada pengukuran pertama dan kedua. 
3. Rata - rata pengetahuan siswa tentang obesitas pada kelompok Perlakuan adalah 5,500 dengan standar deviasi 0.88 . Sedangkan untuk kelompok kontrol ratarata pengetahuan 5.755 dengan standar deviasi 1.04. Hasil uji statistik didapatkan nilai $\mathrm{p}=0.239$, berarti bahwa pada alpha 5 $\%$ terlihat tidak ada perbedaan yang signifikan rata - rata antara pengetahuan siswa pada kelompok perlakuan / teman sebaya dengan kelompok kontrol.

\section{Daftar Pustaka}

Albiner Siagian, Epidemiologi Gizi, Erlangga, Jakarta. 2010.

Badan Kependudukan dan Keluarga Berencana Nasional, Promosi dan Konseling Kesehatan Reproduksi, Jakarta, 2011.

Badan Kependudukan dan Keluarga Berencana Nasional, Pedoman Pengelolaan Pusat Informasi dan Konseling Remaja dan Mahasiswa , Jakarta, 2012

Dwi Nur Wijayanti, Analisis Faktor Penyebab Obesitas dan Cara Mengatasi Obesitas pada Remaja Putri. Skripsi, Universitas Negeri Semarang, 2013

Departemen Kesehatan RI, Pedoman Pelayanan Kesehatan Peduli Remaja di Puskesmas, Jakarta, 2005

Hermanus W, dkk, Efektivitas penggunaan metode teman sebaya terhadap pengetahuan dan sikap seksualitas siswa di SMA Setia Bakti Ruteng tahun 2012, Skripsi, FKM Undana

Ircham Mahfuoedz, Eko Suryani, Pendidikan Kesehatan bagian dari Promosi Kesehatan, Tramaya Yogyakarta, 2006
Luknis Sabri, Sutanto Priyo Hastono, Statistik Kesehatan, PT Raja Grafindo Persada,Jakarta 2006

Martalena, dkk, Hubungan kelompok teman sebaya (peer Group ) dengan prestasi belajar siswa kelas XII IPS di SMAN I Padang Ganting Tanah Datar, Skripsi STKIP PGRI Sumatra Barat 